\title{
Mini Review \\ Systemic Lupus Erythematosus Disease: An Overview of the Clinical Approach to Pathogenesis, Diagnosis, and Treatment
}

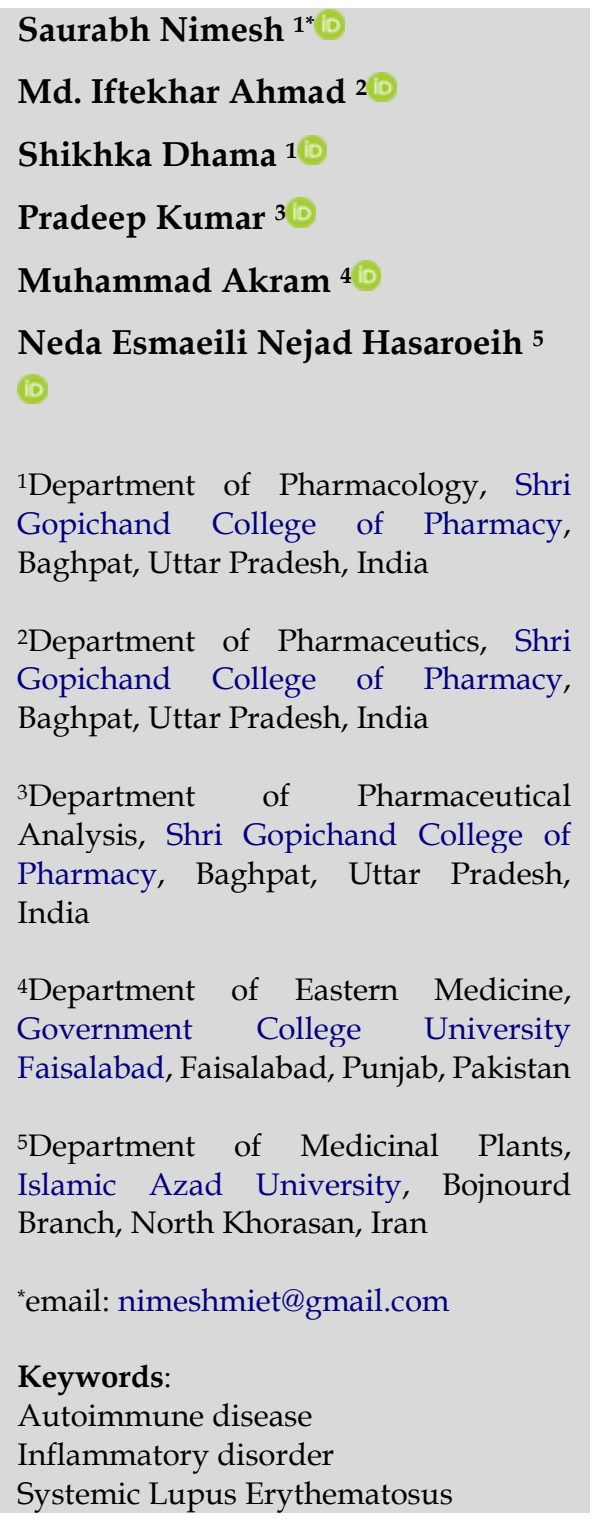

\begin{abstract}
The systemic lupus erythematosus (SLE), commonly known as Lupus, is a rare and complex multisystem autoimmune disease where one's immune system is overactive, and the body attacks its organ systems. SLE is a historically old disease described already in antiquity; it is an example of a chronic disease with physical, psychological, financial, and social implications for individuals diagnosed. It has inspired medical and basic biological scientists that focus on molecular biology, basic immunology, immunopathology, clinical science, genetics, and epidemiology. The syndrome is real in its existence-although hidden behind obstacles, cumbersome for patients and clinicians, and rebellious for scientists. There is currently no cure for SLE. The goal of treatment is to ease symptoms. This article will review information on the general approach to SLE therapy, focusing on currently approved therapies and novel approaches that might be used in the future.
\end{abstract}

Received: December 28th, 2020

Accepted: April 17th, 2021

Published: May 30th, 2021

(c) 2021 Saurabh Nimesh, Md. Iftekhar Ahmad, Shikhka Dhama, Pradeep Kumar, Muhammad Akram, Neda Esmaeili Nejad Hasaroeih. Published by Institute for Research and Community Services Universitas Muhammadiyah Palangkaraya. This is an Open Access article under the CC-BY-SA License

\section{INTRODUCTION}

Systemic lupus erythematosus (SLE or lupus) is one of the most common systemic autoimmune connective tissue diseases. It is characterized by a highly variable clinical presentation that may range from mild skin involvement to life-threatening multi-organ failure1,2.
Some authorities from the government of a country such as The Japanese Ministry of Health, Labor and Welfare even designated SLE as an intractable disease because there is no established way to cure the existing disease, but with appropriate management ${ }^{3}$.

Systemic lupus erythematosus is, without a doubt, a debilitating and life-altering illness. Systemic lupus 
erythematosus may cause severe symptoms such as discomfort, excessive weakness, hair loss, cognitive problems, and physical impairments; many people with SLE develop cardiovascular disease, strokes, disfiguring rashes, and sore joints; and some people with SLE have no apparent symptoms ${ }^{4}$. The etiology of SLE has not yet been elucidated in detail, although genetic factors and environmental factors are thought to play a role in its development ${ }^{5}$. The discrepancies of rates (i.e., higher rates in certain ethnic groups) are due to genetic factors and environmental factors such as smoking and dietary habits 6 .

The history of SLE goes back even further than the $4^{\text {th }}$ century. Hippocrates recorded the documented case of lupus in $400 \mathrm{BC}$. The four main types of lupus are neonatal and pediatric lupus erythematosus (NLE); cutaneous or discoid lupus erythematosus (CLE); druginduced lupus erythematosus (DILE); and SLE, as presented in Table I. Systemic lupus erythematosus can be divided into three periods: the classical period, the neoclassical period, and the modern period. Each period is marked with important discoveries that have allowed a better understanding of this disease ${ }^{8}$. This mini-review will discuss several things related to SLE and its clinical approach, including epidemiology, pathogenesis, diagnosis, and treatment, based on a review of the latest related studies.

\section{EPIDEMIOLOGY}

The SLE is seen worldwide and occurs in all racial or ethnic groups, although regional variations in frequency and severity have been reported ${ }^{9}$. An estimated 5 million people worldwide have some form of lupus disease. The $70 \%$ of lupus cases diagnosed are SLE, $20 \%$ of people with lupus will have a parent or sibling who already has lupus or may develop lupus, and about $5 \%$ of the children born to individuals with lupus will develop the illness ${ }^{10,11}$. Studies have shown that the incidence rate of SLE around the world is about 1 to 10 per 100000 people/years ${ }^{12}$, while the prevalence rates range 3.2 cases per 100000 persons, with the highest prevalence reported in India, and it appears to be increasing as the disease is recognized more readily and survival increases ${ }^{13,14}$. In the US, people of African, Hispanic, or Asian ancestry as compared to those of other racial or ethnic groups, tend to have an increased prevalence of SLE and greater involvement of vital organs ${ }^{15-17}$.

Table I. The four categories of lupus and their descriptions ${ }^{18,19}$

\begin{tabular}{|c|c|}
\hline Lupus types & Descriptions \\
\hline $\begin{array}{l}\text { Neonatal and } \\
\text { pediatric } \\
\text { lupus } \\
\text { erythematosus } \\
\text { (NLE) }\end{array}$ & $\begin{array}{l}\text { Neonatal lupus erythematosus is a rare condition } \\
\text { that affects infants of women who have lupus and } \\
\text { is caused by antibodies (Abs) from the mother } \\
\text { acting upon the infant in the uterus. At birth, the } \\
\text { infantmay havea skin rash, liver problems, or low } \\
\text { blood cell counts, but these symptoms disappear } \\
\text { completely after several months with no lasting } \\
\text { effects }^{20,21} \text {. }\end{array}$ \\
\hline $\begin{array}{l}\text { Cutaneous or } \\
\text { discoid lupus } \\
\text { erythematosus } \\
\text { (CLE) }\end{array}$ & $\begin{array}{l}\text { This form of lupus is limited to the skin. Although } \\
\text { CLE can cause many types of rashes and lesions } \\
\text { (sores), the most common discoid rash is raised, } \\
\text { scaly, and red, but not itchy. Areas of rash appear } \\
\text { like disks or circles. Another typical e.g., of CLE is } \\
\text { a rash over the cheeks and across the bridge of the } \\
\text { nose. Hair loss and changes in the pigment, or } \\
\text { color, of the skin are also symptoms of CLE². }\end{array}$ \\
\hline $\begin{array}{l}\text { Drug-induced } \\
\text { lupus } \\
\text { erythematosus } \\
\text { (DILE) }\end{array}$ & $\begin{array}{l}\text { The symptoms of DILEare similar to those ofSLE, } \\
\text { but it rarely affects major organs. DILE is a lupus- } \\
\text { like disease caused by certain prescription drugs } \\
\text { like Hydralazine, Procainamide, Isoniazid, and } \\
\text { others }{ }^{23} \text {. }\end{array}$ \\
\hline $\begin{array}{l}\text { Systemic } \\
\text { lupus } \\
\text { erythematosus } \\
\text { (SLE) }\end{array}$ & $\begin{array}{l}\text { Systemic lupus erythematosus is the most } \\
\text { common form of lupus-it can be mild or severe- } \\
\text { some of the more severe complications involving } \\
\text { major organ systems. Inflammation of the kidneys } \\
\text { can affect the body's ability to filter waste from the } \\
\text { blood. Inflammation of the nervous system and } \\
\text { the brain's blood vessels can cause high fevers, } \\
\text { seizures, behavioral changes, confusion, } \\
\text { headaches, and strokes }{ }^{24} \text {. }\end{array}$ \\
\hline
\end{tabular}

\section{PATHOGENESIS}

The etiology of SLE is unknown to date. Many factors contribute to SLE development, including genetic, environmental, hormonal, and immunoregulatory factors $^{25-27}$, as described in Figure 1. Certain risk factors have been identified and shown to contribute to disease susceptibility or activate the immune system causing an inflammatory response, ultimately leading to the 
development of the disease ${ }^{28}$. Genetic factors influence predisposition to SLE. The female predominance in SLE may be explained, in part, by the contribution of certain hormones. Environmental factors, such as smoking, exposure to ultraviolet light, viral infections, and specific medications (e.g., sulfonamide antibiotics) are known to trigger SLE29. The pathogenesis of SLE is complex, with contributions from many components of the immune system. With the underlying genetic predisposition and in response to various triggers, the balance of the immune system shifts towards reacting against it rather than selftolerance ${ }^{30}$. The T and B cells become activated, leading to antibody production and eventual immune complex formation. These complexes circulate and deposit in critical tissues causing organ injury ${ }^{31}$.

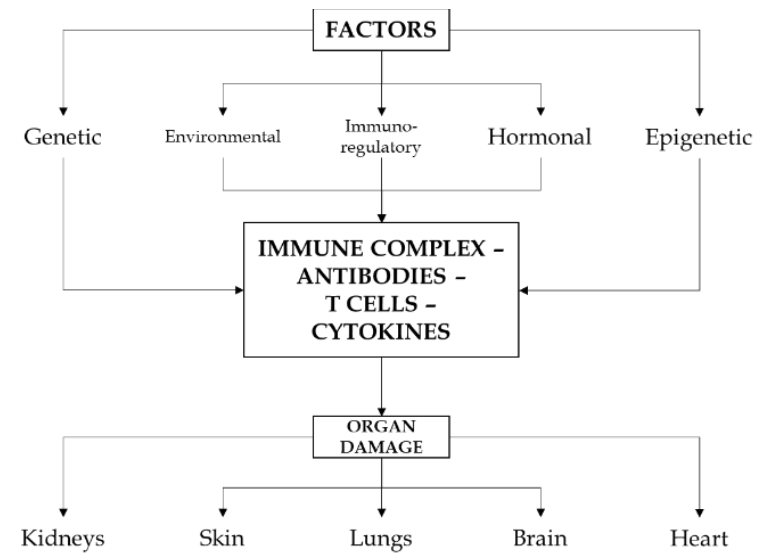

Figure 1. Factors involved in the pathogenesis of $\mathrm{SLE}^{32}$

\section{DIAGNOSIS}

According to the American College of Rheumatology, the diagnosis of SLE is based on the clinical and laboratory criteria ${ }^{33}$, as summarized in Table II. The diagnosis of SLE requires four or more of the following eleven criteria during the observation ${ }^{34}$. Since the early signs and symptoms of SLE are non-specific and can mimic those of other diseases, for example, rheumatoid arthritis, glomerulonephritis, anemia, or dermatitis, it can be challenging to diagnose. The accuracy of diagnosis and early recognition of SLE is essential ${ }^{35,36}$. An algorithm for the diagnosis of the SLE shows in Figure 2.

Table II. Diagnosis of SLE based on clinical and laboratory criteria

\begin{tabular}{cl}
\hline \multicolumn{1}{c}{ Problems } & \multicolumn{1}{c}{ Descriptions } \\
\hline Malar rash & $\begin{array}{l}\text { Fixed erythema, flat or raised, over the } \\
\text { malar eminences, tending to spare the } \\
\text { nasolabial folds. } \\
\text { Eiscoid rash }\end{array}$ \\
& $\begin{array}{l}\text { Erythematous, raised patches with } \\
\text { adherent keratotic scaling and follicular } \\
\text { plugging; possibly atrophic scarring in }\end{array}$
\end{tabular}

Photosensitivity Skin rash as a result of unusual reaction to sunlight, as determined by patient history or physician observation.

Oral ulcers Oral or nasopharyngeal ulceration, usually painless, observed by the physician

Arthritis Non-erosive arthritis involving two or more peripheral joints, characterized by swelling, tenderness, or effusion.

Serositis Pleuritis, by the convincing history of pleuritic pain, rub heard by a physician, or evidence of pleural effusion; or pericarditis documented by electrocardiography, rub heard by a physician, or evidence of pericardial effusion.

Renal Persistent proteinuria, $0.5 \mathrm{~g} /$ day or $>3+$ disorder if quantitation is not performed; or cellular casts (maybe red blood cell, hemoglobin, granular, tubular, or mixed cellular casts)

Neurologic Seizures or psychosis occur in the disorder absence of offending drugs or known metabolic derangement (e.g., uremia, ketoacidosis, electrolyte imbalance).

Hematologic Hemolytic anemia with reticulocytosis; disorder or leukopenia, $4.0 \times 109 / \mathrm{L}$ on two or more occasions; or lymphopenia, $1.5 \times$ $109 / \mathrm{L}$ on two or more occasions; or thrombocytopenia, $100 \times 109 / \mathrm{L}$ in the absence of offending drugs.

Immunologic Antibody to a double-stranded disorder deoxyribonucleic acid antigen (antidsDNA) in abnormal titer; or presence of antibody to Smith nuclear antigen (anti-Sm); or positive finding of antiphospholipid Abs based on an abnormal serum level of Immunoglobulin (Ig) $\mathrm{G}$ or $\mathrm{Ig} \mathrm{M}$ anticardiolipin Abs, a positive test result for lupus anticoagulant using a standard method, or a false positive serologic test for syphilis that is known to be positive for at least six months and is confirmed by negative Treponema pallidum immobilization or fluorescent treponemal antibody absorption test.

Antinuclear An abnormal antinuclear antibodies antibodies (ANA) titer by immunofluorescence or an equivalent assay at any time and in the absence of drugs known to be associated with DILE. 
Patient presenting with disease manifestations involving two or more organ systems

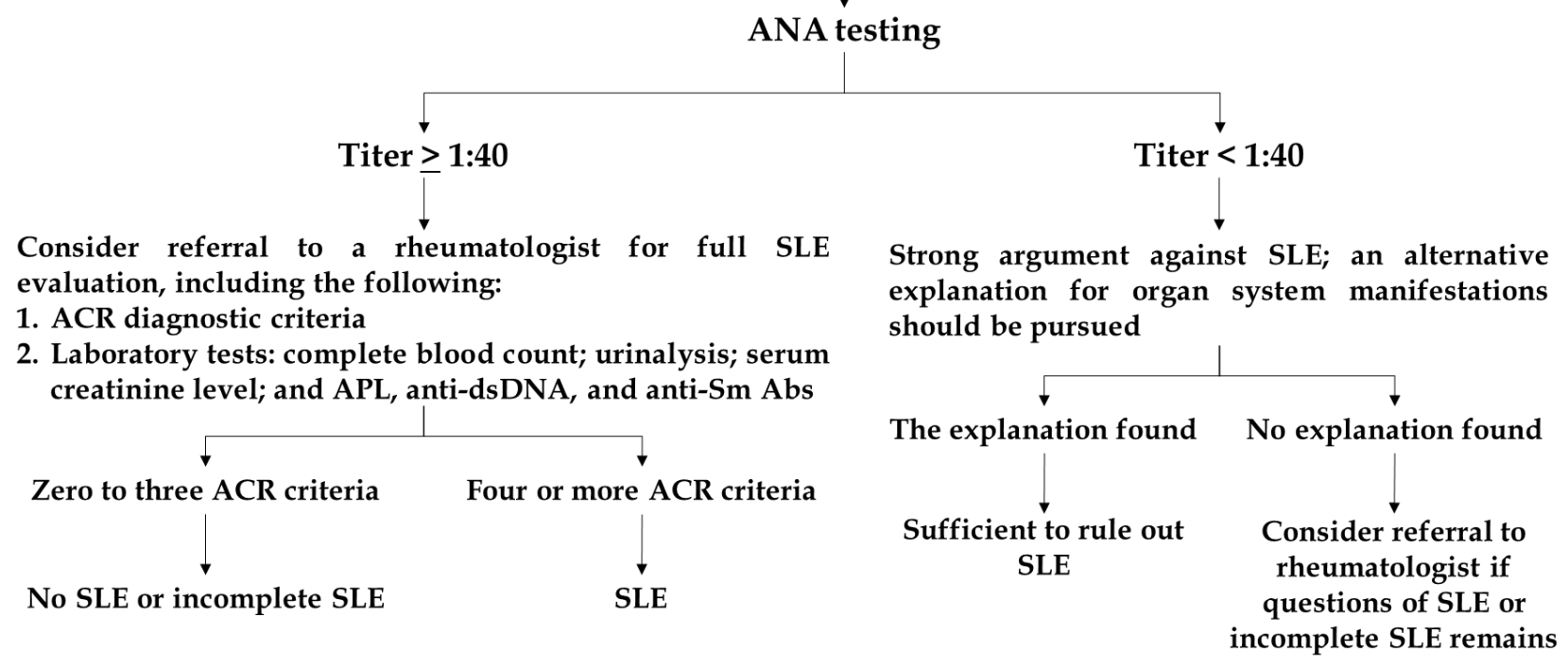

Figure 2. Factors involved in the pathogenesis of $\mathrm{SLE}^{37}$

\section{TREATMENT}

There is no cure for SLE at present, but the condition is most often very treatable and usually responds well to some different types of drugs-especially when treatment is started in the early stages of the disease ${ }^{38}$. Most of the drugs described in Table III were initially developed for other diseases but were later found to be helpful in SLE ${ }^{39}$. There are many levels of severity and complications of SLE that require management. Treatment is dependent on presentation, and options include antimalarials, glucocorticoids, immunosuppressants, and biologics. NSAIDs may also be used to treat inflammation and pain enlisted ${ }^{40}$.

In addition to these therapies, the current development of treatments for SLE has primarily led to the development of monoclonal antibodies ${ }^{41}$, as presented in Table IV. Two newer drugs (rituximab and belimumab) are now sometimes used for the treatment of severe $\mathrm{SLE}^{42}$. Also, several small-molecule inhibitors have shown promising progress in the treatment of SLE. Research is continuing to find out which patients respond best to these drugs ${ }^{43-}$ 45 .
Table III. Common medications to control SLE

\begin{tabular}{|c|c|}
\hline Agents & Descriptions \\
\hline NSAIDs & $\begin{array}{l}\text { Over-the-counter NSAIDs, such as } \\
\text { naproxen sodium and ibuprofen may be } \\
\text { used to treat pain, swelling, and fever } \\
\text { associated with SLE. Stronger NSAIDs are } \\
\text { available by prescription. }\end{array}$ \\
\hline $\begin{array}{l}\text { Anti- } \\
\text { malarial }\end{array}$ & $\begin{array}{l}\text { Drugs commonly used to treat malaria, such } \\
\text { as hydroxychloroquine, affect the immune } \\
\text { system, and decrease the risk of SLE flares. }\end{array}$ \\
\hline $\begin{array}{l}\text { Cortico- } \\
\text { steroids }\end{array}$ & $\begin{array}{l}\text { Prednisone and other types of } \\
\text { corticosteroids can counter the } \\
\text { inflammation of SLE. High doses of steroids } \\
\text { such as methylprednisolone often used to } \\
\text { control serious disease that involves the } \\
\text { kidneys and brain. }\end{array}$ \\
\hline $\begin{array}{l}\text { Immuno- } \\
\text { suppressants }\end{array}$ & $\begin{array}{l}\text { Drugs that suppress the immune system } \\
\text { may be helpful in serious cases of SLE e.g. } \\
\text { azathioprine and methotrexate. }\end{array}$ \\
\hline Biologics & $\begin{array}{l}\text { Biological agents used in the treatment of } \\
\text { SLE include rituximab and belimumab, both } \\
\text { monoclonal antibodies. Rituximab targets B } \\
\text { cells and is used to treat renal and CNS } \\
\text { presentations of SLE. This agent is } \\
\text { recognized as an II- or III-line agent for } \\
\text { active disease. Belimumab targets the B cell- } \\
\text { activating factor B-lymphocyte stimulator. } \\
\text { Belimumab is approved for use in active } \\
\text { disease in conjunction with standard } \\
\text { therapies including glucocorticoids, } \\
\text { antimalarials, NSAIDs, mycophenolate } \\
\text { mofetil, and azathioprine. Other biologics, } \\
\text { such as tumor necrosis factor inhibitors, } \\
\text { abatacept, and tocilizumab, are also } \\
\text { considered. }\end{array}$ \\
\hline Other agents & $\begin{array}{l}\text { Besides the agents listed above, there are } \\
\text { other agents used off-label to treat SLE. } \\
\text { These include disease-modifying } \\
\text { antirheumatic drugs such as methotrexate, } \\
\text { leflunomide, and calcineurin inhibitors } \\
\text { (tacrolimus and cyclosporine). }\end{array}$ \\
\hline
\end{tabular}


Table IV. Summary of new and emerging therapies or clinical trials in the treatment of SLE

\begin{tabular}{|c|c|c|}
\hline Target & Treatment & Status \\
\hline \multicolumn{3}{|l|}{ B cells } \\
\hline \multirow{5}{*}{$\begin{array}{l}\text { BAFF/ } \\
\text { APRIL }\end{array}$} & Belimumab & Approved for non-renal SLE; \\
\hline & & $\begin{array}{l}\text { Ongoing phase-IV for efficacy, } \\
\text { safety, and tolerability; Ongoing } \\
\text { phase-III in combination with } \\
\text { Rituximab. }\end{array}$ \\
\hline & Tabalumab & $\begin{array}{l}\text { Phase-III without significant effect } \\
\text { (terminated). }\end{array}$ \\
\hline & Blisibimod & $\begin{array}{l}\text { Phase-III did not meet the SRI- } 6 \\
\text { primary endpoint. }\end{array}$ \\
\hline & Atacicept & $\begin{array}{l}\text { APRIL-SLE study terminated due } \\
\text { to increased infection rate; } \\
\text { ADDRESS-II study has an } \\
\text { acceptable safety profile. }\end{array}$ \\
\hline \multirow[t]{2}{*}{ CD20 } & Rituximab & $\begin{array}{l}\text { Phase-III failed (nephritis and non- } \\
\text { nephritis). }\end{array}$ \\
\hline & Ocrelizumab & Phase-III trial completed. \\
\hline CD22 & Epratuzumab & Phase-III failed. \\
\hline & & \\
\hline
\end{tabular}

Proteasome Bortezomib Phase-II trial.

inhibitors

\begin{tabular}{|c|c|c|}
\hline \multicolumn{3}{|c|}{ Intracellular signaling } \\
\hline \multirow[t]{2}{*}{ Btk } & M2951 & Ongoing phase-II trial. \\
\hline & Fenebrutinib & Ongoing phase-II trial. \\
\hline \multirow[t]{2}{*}{ mTOR } & $\begin{array}{l}\mathrm{N}- \\
\text { acetylcysteine }\end{array}$ & $\begin{array}{l}\text { A small study showed a decrease } \\
\text { in SLEDAI, with no further } \\
\text { development. }\end{array}$ \\
\hline & Rapamycin & $\begin{array}{l}\text { An open-label study showed an } \\
\text { effect on BILAG. The larger study } \\
\text { was planned. }\end{array}$ \\
\hline JAK/STAT & GSK2586184 & $\begin{array}{l}\text { Ineffective interferon signature in } \\
\text { phase-II, safety data do not } \\
\text { support further study. }\end{array}$ \\
\hline JAK 2 & Baricitinib & $\begin{array}{l}\text { Phase-II positive data; Phase-III } \\
\text { trial ongoing. }\end{array}$ \\
\hline JAK3 & Tofacitinib & Ongoing Phase-I/II trial. \\
\hline$\overline{\mathrm{ROCK}}$ & Fasudil & $\begin{array}{l}\text { Effective in preclinical studies in a } \\
\text { patient with Raynaud's } \\
\text { phenomenon, Phase-III completed } \\
\text { with un-interpretable data. }\end{array}$ \\
\hline
\end{tabular}

Co-stimulation

CD40:CD154DapirolizumabOngoing phase-II trial.

\begin{tabular}{lll} 
& BI 655064 & Ongoing phase-II trial. \\
\hline CD28: B7 & Abatacept & Ineffective in Phase-III in nephritis
\end{tabular}
and general SLE.

Lulizumab Phase-II trial terminated-failed to meet protocol objectives.

\begin{tabular}{|c|c|c|}
\hline \multicolumn{3}{|l|}{ Cytokines } \\
\hline \multirow[t]{6}{*}{ IFN-a } & Sifalimumab & $\begin{array}{l}\text { The limited effect in phase-II and } \\
\text { III. No further development. }\end{array}$ \\
\hline & Rontalizumab & $\begin{array}{l}\text { Phase-II without significant } \\
\text { results. }\end{array}$ \\
\hline & Anifrolumab & $\begin{array}{l}\text { Phase-II positive data; } 2 \text { Phase-III } \\
\text { trials ongoing (one reported } \\
\text { negative). }\end{array}$ \\
\hline & IAGS-009 & $\begin{array}{l}\text { Completed phase-I, no data } \\
\text { released. }\end{array}$ \\
\hline & JNJ-55920839 & In recruiting phase. \\
\hline & IFNa-k & $\begin{array}{l}\text { Successful phase-I; ongoing phase- } \\
\text { II trial. }\end{array}$ \\
\hline \multirow{3}{*}{$\begin{array}{l}\text { Interleukin } \\
\text { (IL)-2 }\end{array}$} & Aldesleukin & Ongoing open-label phase-II trial. \\
\hline & AMG 592 & Ongoing phase-Ib and IIa trial. \\
\hline & ILT-101 & Ongoing phase-II trial. \\
\hline IL-12/23 & Ustekinumab & $\begin{array}{l}\text { Met primary end-point in a phase- } \\
\text { II trial; ongoing phase-III trial. }\end{array}$ \\
\hline
\end{tabular}

\begin{tabular}{lll}
\hline IL-6 & PF-04236921 & $\begin{array}{l}\text { Failed phase-II trial; safety } \\
\text { compromised. } \\
\end{array}$ \\
& $\begin{array}{l}\text { Sirukumab } \\
\text { MRA003US }\end{array}$ & $\begin{array}{l}\text { Failed phase-II trial. } \\
\text { Ongoing phase-II trial. }\end{array}$ \\
& VobarilizumabOngoing phase-I trial. \\
\hline IL-10 & BT063 & Ongoing phase-II trial. \\
\hline Other & & \\
\hline & Lupuzor & $\begin{array}{l}\text { Phase-III trial failed to meet the } \\
\text { primary endpoint. }\end{array}$ \\
\hline
\end{tabular}

\section{CONCLUSION}

Systemic lupus erythematosus is a chronic autoimmune inflammatory disorder that causes significant morbidity and mortality. The disease is a scientifically challenging, problematic, inspiring, and seminal, clinical syndrome. Systemic lupus erythematosus treatment has made significant progress over the past decade; however, the management of SLE is complex, with a multitude of complications and various treatment options. Patients require a comprehensive plan for care and management of complications from both the disease and therapy. Over the past few years, scientific studies and ongoing clinical trials have shifted the paradigm with rapid advances in developing biologics and small molecules.

\section{ACKNOWLEDGMENT}

The authors gratefully acknowledge Prof. Dr. Lubhan Singh, Head of Department of Pharmacology, Kharvel Subharti College of Pharmacy, Subharti University, Meerut, Uttar Pradesh, India, for their valuable discussion and support with manuscript preparation.

\section{AUTHORS' CONTRIBUTION}

All authors made substantial contributions to the conception and writing of this manuscript. All authors read and approved the final manuscript.

\section{DATA AVAILABILITY}

None. 


\section{CONFLICT OF INTEREST}

There are no conflicts of interest.

\section{REFERENCES}

1. Soni C, Reizis B. DNA as a self-antigen: nature and regulation. Curr Opin Immunol. 2018;55:31-7. doi:10.1016/j.coi.2018.09.009

2. Chen $X$, Sun X, Wang W, Yang B, Zhao X, Chen S, et al. An autoimmune disease variant of IgG1 modulates B cell activation and differentiation. Science. 2018;362(6415):700-5. doi:10.1126/science.aap9310

3. Tanaka Y, Mizukami A, Kobayashi A, Ito C, Matsuki T. Disease severity and economic burden in Japanese patients with systemic lupus erythematosus: A retrospective, observational study. Int J Rheum Dis. 2018;21(8):1609-18. doi:10.1111/1756-185X.13363

4. Cojocaru M, Cojocaru IM, Silosi I, Vrabie CD. Manifestations of Systemic Lupus Erythematosus. Maedica. 2011;6(4):330-6.

5. Parks CG, Santos AdSE, Barbhaiya M, Costenbader $\mathrm{KH}$. Understanding the role of environmental factors in the development of Systemic Lupus Erythematosus. Best Pract Res Clin Rheumatol. 2017;31(3):306-20. doi:10.1016/j.berh.2017.09.005

6. Constantin MM, Nita IE, Olteanu R, Constantin T, Bucur S, Matei $C$, et al. Significance and impact of dietary factors on systemic lupus erythematosus pathogenesis. Exp Ther Med. 2019;17(2):1085-90. doi:10.3892/etm.2018.6986

7. Smith $\mathrm{CD}, \mathrm{Cyr} \mathrm{M}$. The history of lupus erythematosus. From Hippocrates to Osler. Rheum Dis Clin North Am. 1988;14(1):1-14.

8. Boumpas DT, Bertsias GK, Fanouriakis A. 2008-2018: a decade of recommendations for systemic lupus erythematosus. Ann Rheum Dis. 2018;77(11):1547-8. doi:10.1136/annrheumdis-2018-214014

9. BaeEH, LimSY, Han KD, JungJH, Choi HS, KimHY, et al. Trend of prevalence and incidence of systemic lupus erythematosus in South Korea, 2005 to 2015: a nationwide population-based study. Korean J Intern Med. 2020;35(3):652-61. doi:10.3904/kjim.2018.303
10. Fava A, Petri M. Systemic Lupus Erythematosus: Diagnosis and Clinical Management. J Autoimmun. 2019;96:1-13. doi:10.1016/j.jaut.2018.11.001

11. Stojan G, Petri M. Epidemiology of Systemic Lupus Erythematosus: an update. Curr Opin Rheumatol. 2018;30(2):144-50. doi:10.1097/BOR.0000000000000480

12. Fatoye F, Gebrye T, Svenson LW. Real-world incidence and prevalence of systemic lupus erythematosus in Alberta, Canada. Rheumatol Int. 2018;38(9):1721-6. doi:10.1007/s00296-018-4091-4

13. Bharath G, Kumar P, Makkar N, Singla P, Soneja M, Biswas A, et al. Mortality in systemic lupus erythematosus at a teaching hospital in India: A 5year retrospective study. J Family Med Prim Care. 2019;8(7):2511-5. doi:10.4103/jfmpc.jfmpc_362_19

14. Osio-Salido E, Manapat-Reyes H. Epidemiology of systemic lupus erythematosus in Asia. Lupus. 2010;19(12):1365-73. doi:10.1177/0961203310374305

15. Gergianaki I, Bertsias G. Systemic Lupus Erythematosus in Primary Care: An Update and Practical Messages for the General Practitioner. Front Med. 2018;5:161. doi:10.3389/fmed.2018.00161

16. Williams EM, Bruner L, Adkins A, Vrana C, Logan A, Kamen D, et al. I too, am America: a review of research on systemic lupus erythematosus in AfricanAmericans. Lupus Sci Med. 2016;3(1):e000144. doi:10.1136/lupus-2015-000144

17. Olesińska M, Saletra A. Quality of life in systemic lupus erythematosus and its measurement. Reumatologia. 2018;56(1):45-54. doi:10.5114/reum.2018.74750

18. Bajema IM, Wilhelmus S, Alpers CE, Bruijn JA, Colvin RB, Cook HT, et al. Revision of the International Society of Nephrology/Renal Pathology Society classification for lupus nephritis: clarification of definitions, and modified National Institutes of Health activity and chronicity indices. Kidney Int. 2018;93(4):789-96. doi:10.1016/j.kint.2017.11.023

19. Fanouriakis A, Kostopoulou M, Alunno A, Aringer M, Bajema I, Boletis JN, et al. 2019 update of the EULAR recommendations for the management of systemic lupus erythematosus. Ann Rheum Dis. 2019;78(6):736-45. doi:10.1136/annrheumdis-2019215089 
20. Hon KL, Leung AKC. Neonatal Lupus Erythematosus. Autoimmune Dis. 2012;2012:301274. doi:10.1155/2012/301274

21. Costagliola G, Mosca M, Migliorini P, Consolini R. Pediatric Systemic Lupus Erythematosus: Learning From Longer Follow Up to Adulthood. Front Pediatr. 2018;6:144. doi:10.3389/fped.2018.00144

22. Okon LG, Werth VP. Cutaneous Lupus Erythematosus: Diagnosis and treatment. Best Pract Res Clin Rheumatol. 2013;27(3):391-404. doi:10.1016/j.berh.2013.07.008

23. Sarzi-Puttini P, Atzeni F, Capsoni F, Lubrano E, Doria A. Drug-induced lupus erythematosus. Autoimmunity. doi:10.1080/08916930500285857

24. Rekvig OP. Systemic Lupus Erythematosus: Definitions, Contexts, Conflicts, Enigmas. Front Immunol. 2018;9:387. doi:10.3389/fimmu.2018.00387

25. Moulton VR, Suarez-Fueyo A, Meidan E, Li H, Mizui M, Tsokos GC. Pathogenesis of Human Systemic Lupus Erythematosus: A Cellular Perspective. Trend Mol Med. 2017;23(7):615-35. doi:10.1016/j.molmed.2017.05.006

26. Barbhaiya M, Costenbader KH. Environmental Exposures and the Development of Systemic Lupus Erythematosus. Curr Opin Rheumatol. 2016;28(5):497-505. doi:10.1097/BOR.0000000000000318

27. Arneth B. Systemic Lupus Erythematosus and DNA Degradation and Elimination Defects. Front Immunol. 2019;10:1697. doi:10.3389/fimmu.2019.01697

28. Zharkova O, Celhar T, Cravens PD, Satterthwaite AB, Fairhurst AM, Davis LS. Pathways leading to an immunological disease: systemic lupus erythematosus. Rheumatology. 2017;56(suppl_1):i55i66. doi:10.1093/rheumatology/kew427

29. Pan Q, Chen J, Guo L, Lu X, Liao S, Zhao C, et al. Mechanistic insights into environmental and genetic risk factors for systemic lupus erythematosus. Am J Transl Res. 2019;11(3):1241-54.

30. Pan L, Lu MP, Wang JH, Xu M, Yang SR. Immunological pathogenesis and treatment of systemic lupus erythematosus. World J Pediatr. 2020;16(1):19-30. doi:10.1007/s12519-019-00229-3
31. Liao X, Reihl AM, Luo XM. Breakdown of Immune Tolerance in Systemic Lupus Erythematosus by Dendritic Cells. J Immunol Res. 2016;2016:6269157. doi:10.1155/2016/6269157

32. Avasare RS, Yee J. Lupus Nephritis: Breaking the Lull. Adv Chronic Kidney Dis. 2019;26(5):307-10. doi:10.1053/j.ackd.2019.05.005

33. Kuhn A, Bonsmann G, Anders HJ, Herzer P, Tenbrock K, Schneider M. The Diagnosis and Treatment of Systemic Lupus Erythematosus. Dtsch Arztebl Int. 2015;112(25):423-32. doi:10.3238/arztebl.2015.0423

34. Aringer M, Leuchten N, JohnsonSR. New Criteria for Lupus. Curr Rheumatol Rep. 2020;22(6):18. doi:10.1007/s11926-020-00896-6

35. Vasquez-Canizares N, Wahezi D, Putterman C. Diagnostic and Prognostic Tests in Systemic Lupus Erythematosus. Best Pract Res Clin Rheumatol. 2017;31(3):351-63. doi:10.1016/j.berh.2017.10.002

36. Adamichou C, Bertsias G. Flares in systemic lupus erythematosus: diagnosis, risk factors and preventive strategies. Mediterr J Rheumatol. 2017;28(1):4-12. doi:10.31138/mjr.28.1.4

37. Lam NCV, Ghetu MV, Bieniek ML. Systemic Lupus Erythematosus: Primary Care Approach to Diagnosis and Management. Am Fam Physician. 2016;94(4):284-94.

38. Basta F, Fasola F, Triantafyllias K, Schwarting A. Systemic Lupus Erythematosus (SLE) Therapy: The Old and the New. Rheumatol Ther. 2020;7(3):433-46. doi:10.1007/s40744-020-00212-9

39. Ruiz-Irastorza G, Bertsias G. Treating systemic lupus erythematosus in the 21st century: new drugs and new perspectives on old drugs. Rheumatology. 2020;59(Suppl

5):v69-v81. doi:10.1093/rheumatology/keaa403

40. Durcan L, O'Dwyer T, Petri M. Management strategies and future directions for systemic lupus erythematosus in adults. Lancet. 2019;393(10188):2332-43. doi:10.1016/s01406736(19)30237-5

41. Touma Z, Gladman DD. Current and future therapies for SLE: obstacles and recommendations for the development of novel treatments. Lupus Sci Med. 2017;4(1):e000239. doi:10.1136/lupus-2017-000239 
42. Liossis SN, Staveri C. What's New in the Treatment of Systemic Lupus Erythematosus. Front Med. 2021;8:655100. doi:10.3389/fmed.2021.655100

43. Durcan L, Petri M. Why Targeted Therapies are Necessary for Systemic Lupus Erythematosus. Lupus. 2016;25(10):1070-9.

doi:10.1177/0961203316652489

44. Vukelic M, Li Y, Kyttaris VC. Novel Treatments in Lupus. Front Immunol. 2018;9:2658. doi:10.3389/fimmu.2018.02658

45. Sciascia S, Radin M, Roccatello D, Sanna G, Bertolaccini. Recent advances in the management of systemic lupus erythematosus. F1000Res. 2018;7: F1000 Faculty Rev-970. doi:10.12688/f1000research.13941.1 